\title{
On the 'Impossibility' of Atheism in Secular India
}

\author{
Stefan Binder
}

\section{Introduction}

This contribution examines the precarious role of atheism in the framework of contemporary imaginaries of the Indian nation. While atheists and the irreligious of various kinds certainly exist in India_-and have existed in the past - they tend to be marginalized in both public and academic discourses on Indian society, national culture and politics. This can manifest itself in different ways, for example, by ignoring irreligious identities and forms of life, by denigrating them as culturally inauthentic products of colonial, 'Western' or otherwise foreign influence or by relegating them to a sphere of elite Sanskrit philosophy in the pre-colonial past with none but the most tenuous relevance for popular culture and everyday life in the present. In this chapter, I look more closely at this marginalization in order to highlight how it ties into a specific nationalist imaginary in India, which does not presuppose an outright denial or

S. Binder $(\bowtie)$

University of Zurich, Zürich, Switzerland

e-mail: stefan.binder@isek.uzh.ch 
unqualified disavowal of atheism but rather an imagination of atheism as 'impossible'. This imagination of impossibility is pervasive in so far as it is grounded in certain assumptions about religion, morality, individual agency, social responsibility and communal as well as national belonging (if not sociality as such) that are also shared by some people in India who do, in fact, identify with atheism and irreligion.

As such, notions of impossibility are neither a mere misrepresentation belied by the existence of atheists nor an essential attribute of atheismor a specifically 'Indian' cultural variant of it. Instead, I approach them similarly to how James Laidlaw's Jain interlocutors in North India explained that Jainism is impossible for laypeople who do not follow the ideal path of ascetic renouncers:

By this they did not mean either that it is unclear what its teachings are or that it is literally impossible to follow them. ... [A] good lay Jain, as a renouncer necessarily cannot, should venerate, protect, and materially support those renouncers who do follow the soteriological path; but this, because it requires good public standing, political and material resources, and the rearing of a new generation who might be recruits to the order themselves or patrons to support it in their turn, conflicts directly with the central precepts of virtuous ascetic life itself. The more you are a good lay Jain, the less you can be a true Jain. (2014: 126)

Jainism is impossible in the sense that competing moral values attached to renunciation and worldly life give rise to a situation in which the practical conditions necessary to realize one value fully effectively undercut or preclude the other value. While impossibility is in this case internal to the social structure of the Jain community (see also Sethi 2012), I propose to approach the impossibility of atheism as a historically contingent effect of a specific configuration of Indian nationalism, which makes the idea of atheism as a socially viable way of life neither unthinkable nor necessarily undesirable but, at the end of the day, practically impossible.

Benedict Anderson (1983) famously described the genesis of nationality or nation-ness as emerging from an imagined community enabled, among other things, by certain forms of media-especially the novel and the newspaper-and the nationalization of particular vernacular 
languages within a larger political-economic regime of print capitalism. In contrast to dynastic social formations, which are defined by sacred languages, divinely legitimated hierarchies and centres of sovereignty, the nation as an imagined community is premised on the idea of a clearly and territorially bounded 'society', which allows complete strangers and various forms of political and economic inequality to cohere in a 'horizontal comradeship' (ibid.: 7). While certain aspects of Anderson's account have been criticized (e.g. Kelly 2001; Meyer 2009), his focus on the role of mass media and on their regimes of production, distribution and consumption has proved immensely productive for a vast body of both historical and anthropological scholarship on the genesis, continuous transformation and functioning of nationalism and various projects of nation-building (for examples from South Asia, see Dalmia 1997; Mankekar 1999; Rajagopal 2001; Blackburn 2003; Roy 2007; Datla 2013).

Against this background, I analyse cinematic representations of atheism in two recent, commercially successful Bollywood movies, $O M G-O h$ My God! (2012) and PK (2014), in order to elucidate how the frameworks of religious nationalism and state secularism structure the impossibility of atheism in India. Both films sparked protests from Hindu nationalist groups, which criticized them for being offensive and for veiling antiHindu sentiment behind a specious veneer of a more general critique of religion. While such reactions are a seemingly obvious way to link these instances of cinematic atheism within a discursive framework of religious and more specifically Hindu nationalism, I propose to approach them from a different direction, namely the generally positive and favourable reactions they have received from atheists.

However, I am not pursuing an ethnographic account of either the consumption of these two films or specific atheist interpretations; rather, my point of departure is the observation that my atheist interlocutors in Telugu-speaking South India found in the films' protagonists viable foils for positive engagement (projection, recognition, identification etc.) despite the films' explicit depiction of the failure and/or impossibility of atheism. By taking this route, it is possible to examine how the impossibility of atheism is not merely the product of a religious or Hindu nationalist perspective but a constitutive aspect of a larger national frame of reference in which atheists themselves are suspended as well. As already 
mentioned, I do not claim that impossibility is a necessary, essential or transhistorical attribute of 'atheism as such' or of all possible ways of thinking about atheism in India; instead, I argue that it is an aspect of a specific Indian nationalist imaginary, which resonated in significant ways with how the self-identified atheists in South India among whom I have conducted ethnographic research thought about the problem of putting atheism into practice (for other anthropological accounts of atheism(s) in India, see e.g. Quack 2012; Thomas 2017).

\section{Organized Atheism, Religious Nationalism and State Secularism}

My observations are based on fourteen months of fieldwork with members of a loosely organized irreligious movement in Andhra Pradesh and Telangana, which consisted of a heterogeneous array of informal groups, officially registered organizations and networks of more or less active, sympathetic individuals (Binder 2020). Most members of the movement were middle-aged and senior men who hailed from Telugu-speaking and Hindu backgrounds and could be placed somewhere on a middle-class spectrum. Questions of caste were precarious and fiercely contested precisely because the movement was based on an unequivocal rejection of the caste system. While officially disavowed, people's caste identities, especially the upper-caste backgrounds of leaders as well as entire factions of the movement, were still remembered and, so the mutual accusations went, were not at all a question of the past. While not all of my interlocutors considered 'atheism' (nāstikatvam) a suitable name for their movement, and some preferred labels like 'humanism' (mānavavādam) or 'rationalism' (hètuvādam), they all agreed that the lack of belief in the existence of $\operatorname{god}(s)$ was a basic premise of their world view. Hence, the disagreement about names revolved mainly around the question of which label communicated most effectively, in the context of social activism, the movement's claim that irreligion goes far beyond the mere denial and debunking of religious beliefs. 
My interlocutors criticized religions not only as specific belief systems but also as a style and strategic method of social organization, which they considered to be based on exploitation, inequality and 'blind belief' (müdhanammakam) in coercive customs and traditions. The aim of their movement was to implement atheism as a practical 'way of life' (jivitavidhānam) and thereby achieve a comprehensive 'reconstruction of society' (samghanirmānam) without religion, but also without other forms of so-called mental slavery (bhāvadāsyam) that may not be readily recognizable as 'religious' in the narrow sense, such as political authoritarianism or capitalist consumerism. However, precisely because my interlocutors did not reduce atheism to questions of an individual lack of belief but insisted that it should entail a collective and enduring way of life- a material culture, a collective memory of historical continuity, mechanisms of reproduction, procedures for delimiting and policing communal boundaries and so forth-their ideal of practical atheism also risked replicating what they themselves considered a defining problem of mental slavery: the tendency of dynamic, rational and reflexive ways of life to ossify into obdurate and mindless tradition. The movement was acutely aware of the potential of organized atheism to devolve into a 'godless theism' (Gora 1972: 5) or 'merely another Hindu atheist tradition' (Venkatadri 2007: 192), and rival factions within the movement regularly accused one another of being caught up in such processes of devolution.

Though none of my interlocutors used the word 'impossible' to describe this predicament, which they tended to consider a concrete practical and moral challenge, it is similar to the structural impossibility of Jainism referred to by Laidlaw (mentioned earlier) and also resonates with Webb Keane's (2013) semiotic analysis of the 'uninhabitability' of secularism as a moral narrative of modernity. While it is important to stress that secularism cannot be equated with irreligion, the actual relationship between secularism and irreligion-or religion and irreligion for that matter-has until recently received scant attention from critical scholarship on secularism. The important critical insight into the ideological or discursive nature of secularism has resulted in a tendency to efface methodologically rather than theorize or empirically describe the difference between religion and irreligion in terms of a lived, embodied 
and material phenomenon (Binder 2019; see also Blanes and OustinovaStjepanovic 2015; Lee 2015; Scheer et al. 2019). It has also prevented more sustained inquiries into the actual role that impossibility or uninhabitability may play for people who insist on being irreligious. To reiterate my argument: in so far as the impossibility of atheism as a practical project is embedded in a larger conceptual and institutional configuration of religious nationalism and state secularism, it does not follow that atheists cannot pursue that project; rather, they can pursue it within that configuration and, therefore, as an impossibility.

Peter van der Veer $(1994,2001)$ has retraced the imperial and transactional history of that configuration by showing how religious nationalism and secularism are two intrinsically related and co-constitutive aspects of the nation state understood as a global political project, a form of governmentality and an epistemological regime. Van der Veer conceptualizes religious nationalism and secularism as operative discourses and institutional apparatuses through which various projects of religious reform and state regulation shape existing historical 'material' (practices, ideas, social relations, symbols, rituals, forms of personhood, sacred objects and spaces etc.) into a coherent form of 'modern religion' (see also Kippenberg 2001; Masuzawa 2005; Chidester 2014). By being modernized and nationalized within the framework of the secular nation state, 'religion becomes one of the fields of disciplinary practice in which the modern civil subject is produced' (van der Veer 2001: 33). As such, it is part of a solution to the problems of national unity and political loyalty with which nation states are confronted due to their inherent heterogeneity and the presence-and indeed production-of minorities of various kinds (Mahmood 2016).

The nationalization of religion hinges on what van der Veer calls a 'syntagmatic chain' (2014: 9) of a whole range of conceptual by-products like superstition, magic, communalism, secularity, science or spirituality, which are instrumental for defining the nature and boundaries of religion in a given context. In India, spirituality in particular has played a vital role in both anticolonial nationalism and postcolonial secularism, given its ability to signify a common principle of unity for an Indian nation otherwise defined in terms of religious pluralism. The nexus of spirituality and secularism, in its concrete 'Indian' form of nationalized 
religious pluralism, is central to an understanding of atheism's impossibility because that nexus is an important location of the concept of a 'way of life'. Especially in critical debates on Indian secularism since the 1990s, the supposedly impermeable boundaries erected by modern and nationalized religions, referred to as communalism, have been contrasted with more benign forms of Indian spirituality manifested not as bounded religions but in inchoate and popular ways of life. Since those ways of life are considered, at least potentially, to be open to syncretism and plurality, they are supposed to transcend religious boundaries as well as the binary logic of an essentialized distinction between the religious and the secular (Bhargava 1998; Needham and Sunder Rajan 2007; Tejani 2008).

Rather than reviewing the details of this debate-or critical assessments of it (e.g. Ahmad 2009) - I prefer to emphasize that, irrespective of whether the Indian nation is considered to consist of bounded religious communities or fluid ways of life, atheism or irreligion is usually not one of them. This becomes most explicit in staple reiterations by politicians and academics alike that secularism - at least in India-is not irreligious but rather a form of tolerance, regulation or indeed celebration of religious pluralism (cf. Bajpai 2018). As a consequence, critical debates tend to focus on whether this religious pluralism is skewed towards one or other religious community, while its character as not irreligious usually goes unquestioned. In the following engagement with cinematic representations of atheism in two Bollywood films, I seek to illustrate how the disavowal of irreligiosity does not simply eject atheism from the framework of Indian nationalism but includes it in the form of an impossibility.

Anthropological studies of the relationship between nationalism and modern mass media, especially television and cinema, have stressed the importance of analysing media texts or content in the context of more complex 'media practices' (Couldry 2004: 127). By looking not only at the production, circulation and reception of media texts but also at the practices and discourses around, about or oriented towards them, ethnographic studies have foregrounded the fissures, discursive slippages and open-endedness of messages that are broadcast within different projects of mass-mediated 'national pedagogy' (Abu-Lughod 2005: 10; see also Mankekar 1999; Meyer 2015; Bhrugubanda 2018). Rather than 
attempting an ethnography of media practices, my aim in the following is more modest in that I limit myself to a close reading of the plots of two audiovisual media texts in order to illustrate how the impossibility of atheism thrives on conceptual slippages, most importantly between atheism and irreligion, and between religious critique and irreligious criticism. ${ }^{1}$

\section{The Atheist as Failure in OMG—Oh My God!}

The Hindi movie $O M G-O h$ My God! was released in 2012 and later remade in Telugu (Gopala Gopala, 2015) and Kannada (Mukunda Murari, 2016). It announces itself as an adaptation of a Hindi play (Kishan vs. Kanhaiya), which in turn is based on the 2001 Australian comedy, The Man Who Sued God. The film follows Kanji Lalji Mehta, a staunch and vocal atheist, who earns his livelihood by foisting overpriced religious idols and faked sacred ware on to his naïve customers. When Kanji disrupts a religious festival, in which his family members participate against his wishes, and the presiding Hindu priest threatens him with divine punishment for this sin, Kanji brushes aside the warning and openly challenges God. Promptly, an earthquake hits the city, and Kanji's shop is utterly destroyed, while the rest of his neighbourhood remains unscathed. $\mathrm{He}$ still rejects explanations of divine punishment, remains steadfast in his lack of belief in God, even boldly reiterating it and instead trusts in his insurance policy.

The insurance company, however, refuses to pay, arguing that earthquakes are 'acts of God' not covered by his policy. Kanji therefore decides to sue God for indemnities via his earthly representatives. In the course of a protracted lawsuit, which arouses immense media publicity, he loses his livelihood, his family and friends leave him, and his continuing blasphemies make him the target of the violent ire of devotee mobs orchestrated by the villainous godmen, and one godwoman, whom he opposes in court. However, it is the god Krishna himself who descends to earth in the guise of a hotshot, motorcycle-riding real estate agent and not only rescues Kanji from physical danger, homelessness and social isolation, but also provides him with the decisive clue to win his lawsuit. Krishna 
nudges him to study the Bhagavad Gita and other sacred scriptures on whose basis he will prove the liability of god's earthly representatives in court. Kanji himself remains an atheist until right before the verdict, when he falls into a coma and the doctor informs his family that now only God can save him. Indeed, Krishna finally reveals himself to the comatose Kanji and informs him that his enemies have in the meantime been amply compensated for their defeat in court, namely by monetizing the idea that Kanji is the latest spiritual guru and religious reformer. After a scene of tender love in which Kanji asks forgiveness, he wakes up, destroys his own idols and even saves his enemies from the duped mob that has turned against them at last. The movie ends by enjoining the people to eschew self-appointed godmen and look for God directly in fellow humans. In a final epiphany, Krishna reminds Kanji that love, not fear, is at the heart of religion.

Although this moral conclusion iterates one of the commonest atheist arguments against religion, namely that it is driven by fear, my reading of it suggests that it effectively cements the impossibility of atheism in a more fundamental way than the simply incontrovertible existence of the god Krishna throughout the plot. From an atheist's perspective, Kanji's final 'conversion' is deplorable because it evokes a common trope of atheist failure by depicting a lack of belief as a temporary and ultimately deficient phase to be overcome in a transition towards a better understanding of religion. After all, throughout the film Kanji is depicted as consistently fearless and unassailable in his atheism until the very matterof-factness of god's presence simply leaves him no other choice. While devoid of fear, Kanji was not lacking love; in fact, his character is an utterly likeable and caring family man, he is well-integrated into his neighbourhood, and his somewhat excessive rigour and stubbornness still remain within the limits of appropriate masculinity. The film presents his bold atheism in humorous and endearing ways, and he is clearly intended as the main figure of positive identification for viewers (which may fail, of course). Even his morally questionable fraudulence as a businessmanselling tap water as holy water from the Ganges, for example-is justified in so far as his foolish customers seem almost determined to be cheated and merely prove Kanji's point that religion is above all a means to mint money out of blind belief. 
The movie's narrative style and portrayal of its characters provide Kanji's perspective with constant support. His performances of sober reasoning — critics may say specious argument_-are depicted as universally persuasive and go largely unchallenged, except for desperate emotional outrage at their blasphemous nature by his villainous enemies. His court case evolves into a class action with a host of plaintiffs from all the major religious communities in India, and Krishna himself is depicted as utterly enjoying the TV broadcasts of Kanji's rationalist dismantling of religion. And yet, Kanji finds himself economically destitute, socially isolated, publicly scorned, physically attacked and blithely unaware of being saved repeatedly by the very god he denies. It is Kanji's impeccable and unwavering embodiment of the ideal, prototypical male atheist that seems effectively to drive home the point that his ultimate abandonment of atheism is not due to any personal failure on his part but is due to the more general impossibility of atheism.

The film's investment in a hallowed discourse of humanist spirituality (love God by loving your fellow humans), well-entrenched through nationalist discourses of religious reform (Chatterjee 1983; Jones 1989; Radice 1999), fully supports Kanji's atheist critique that institutional religion is largely an insincere and fraudulent human artifice maintained through familial pressures and notions of social respectability. At the same time, however, it is precisely this social aspect, rather than the plot's insistence on God's existence, which makes a total rejection of all spirituality - and not just certain 'bad' forms of institutionalized religionimpossible. Hence, the decisive moment of atheism's impossibility is not its factual cancellation by the presence of God but the plot's insistence that, while Kanji was being an atheist, he spiralled into a state of utter social isolation and, therefore, material destitution, which he could not have sustained if it had not been for (covert) Krishna's assistance.

This also brings us back to a crucial feature of the discourse on Indian secularism, which tends to entertain an Orientalist, largely unquestioned common sense that Indian civilization somehow is, has been and will remain beholden to a basic, ineradicable religiosity. As a result, the secularity of the Indian state-in its ideal form and in contrast to society, the people or indeed the nation - has nothing to do with irreligion, as it refers to things like equidistance from all religions, religious tolerance or 
neutrality (Tejani 2008; Bajpai 2018: 206-268). While there are certainly important nationalist figures like Jawaharlal Nehru, Muhammad Ali Jinnah or Bhagat Singh, who are famous for their aloofness from religion or, in the latter's case, an explicit commitment to atheism, their personal religiosity or lack thereof tends to be put aside as simply that: personal and, as a consequence, impossible or unnecessary as a model for the wider Indian population and the building of a secular national community (e.g. Khilnani 2007). The courts and legal system, more than the government, the state or its personal representatives, are usually treated as the ultimate locus where this model of secularism as a not irreligious equidistance from (all) religions is played out more or less successfully.

Since $O M G$ revolves around a court case, it directly taps into this imaginary of the secular state, the religious nation and, I argue, the impossible atheist. In fact, the somewhat 'anglicized' judge, Kanji's pious Muslim lawyer and even the opportunistic insurance company are perfect embodiments of the ideal of Indian secularism in so far as they abstract from whatever personal or 'sentimental' investment they may have in religion and engage with it in entirely instrumental terms, whether as a matter of legal adjudication (judge), professional duty (lawyer) or economic interest (insurance). Kanji's calm and rational demeanour in court contrasts strikingly with the unrestrained, hysterical and abusive display of emotions by his religious opponents. Kanji thus approaches the court as a secular citizen whose personal beliefs/disbeliefs should not matter, however incendiary they may be, as long as he can provide legal evidence for his case. The evidence in this instance is the very same sacred scriptures he personally rejects (for a historical perspective on the evidentiary role of texts, including opponents' texts, see Appadurai 1981). He wins the case, and the ideally operating secularism of $O M G$ would actually undergird his atheism if it weren't for the 'common people' who manage to transform even a staunch atheist and blasphemer like Kanji into yet another deity, and his radically irreligious critique into yet another reform of religion. This, too, is a common atheist trope, ${ }^{2}$ which the film adopts but turns against atheism by projecting it as a natural and inevitable process that may validate atheist critique of religion but makes the practical implementation of its consequences nonetheless impossible. 
Throughout the film, media coverage of Kanji's atheism, especially on television, constitutes the operative link between secular state and religious nation, court and people, and thus indicates the crucial role that scholars have accorded to transforming media environments for the production and evolution of religious nationalism (Lutgendorf 1990; Rajagopal 2001; Ahmad 2019). The role of media comes to the fore in a more pronounced way in the following example, the movie $P K$, where atheism articulates more explicitly with the ambivalent relationship between immediacy and technological mediation.

\section{The Atheist as Alien in $P K$}

$P K$, released in 2014, is the story of an extraterrestrial, humanoid researcher — named PK—on a field trip to Planet Earth. Shortly after his arrival in rural Rajasthan, the first human he meets steals the remote control for his spaceship, which looks like a gemstone, and sells it to a Hindu godman in New Delhi. The film's plot follows the alien's tumultuous quest to retrieve the device in order to return home. The story is framed by a subplot of a young Indian (Hindu) woman, Jaggu, and a Pakistani (Muslim) man, Sarfaraz, who meet in Belgium, fall in love and decide to get married. In doing so, they defy the objections of Jaggu's family, whose spiritual guru, Tapasvi Maharaj, predicted that Sarfaraz, being a Muslim, would betray Jaggu. Due to an unfortunate misunderstanding in the wedding chapel, Jaggu believes the prophecy has come true, cancels the marriage before Sarfaraz can clear up the confusion and returns to Delhi, where she starts working as a TV journalist. As it so happens, Jaggu's family guru is the godman who has acquired the extraterrestrial remote, which he passes off as a bead from Lord Shiva's necklace that he claims to have received while meditating in the Himalayas. At the end of the film, the alien exposes Tapasvi Maharaj as a fraud during a live talk show on Jaggu's TV channel and reunites her in the process with Sarfaraz, who has returned to Lahore.

While Kanji in $O M G$ is an explicit atheist from an equally explicitly Hindu background, who engages with religion in the context of and ideal image of the state's religiously neutral secularity, $P K$ s extraterrestrial 
researcher embodies that equidistant, neutral secularity himself. The state in $P K$ is represented by the police, not the court, and is much less efficient, as a police officer is the first to introduce the concept of God to the alien. He comments on the absurdity of the alien's request to retrieve a stolen remote control in a city like New Delhi by telling him sarcastically: 'I am not God'. This instance of figurative speech kicks off the film's main plot, as the alien attempts to get in touch with God by means of all the different religions he finds in Delhi, as he assumes that only God can help him in his search for the remote. It is precisely his unprejudiced, sincere and logical but utterly naïve or literal engagement with all religions that gradually reveals the hypocrisy, bigotry and fraudulence that, as the film suggests, marks all of them equally to the extent that they function as social institutions.

In his journey through the religious landscape of contemporary urban India, PK constantly becomes enmeshed in mostly humorous situations that stage a fairly common repertoire of religious critique revolving, as is the case in $O M G$, around the monetization of belief and the merely human-made nature of institutional religion. Metaphors of religion are drawn mostly from the economic sphere, for example, when godmen are referred to as managers of God, worship is depicted as bribery or religious belonging is construed in terms of a (fashion) label. In contrast to $O M G$, however, the existence of God is never denied nor considered as a significant theme by either the characters or the movie as a whole. Our alien can still be called an atheist, as he initially lacks any concept whatsoever of either God or religion. There simply isn't anything for him to deny.

While Kanji is a Hindu who rejects his and by extension all other religions, the alien stands in an entirely external relation not only to religion but also to all other aspects of human culture; and this connection between religion and culture already prefigures atheism's impossibility in $P K$. The alien arrives on earth completely naked and without language, as his species communicates by mindreading through physical touch; he cannot speak and cannot lie. The alien thus embodies an imagined state of 'bare humanism', and his exercise of pure logic, unencumbered by any form of prior knowledge or bias, exposes religions and, especially, their differences to be based on merely arbitrary and superficial social conventions. The film's humorous mode of critique thrives on the fact that the 
alien's use of logic leads him to constantly violate norms of social, religious and gender difference in his quest to understand and imitate human behaviour. Because of his strange and deviant conduct, people assume he is drunk, pike in Hindi-Urdu; so, he starts calling himself PK. Whereas $O M G$ staged an irrational and hollow religion as a set-up for making the critique of an antagonistic and cynical atheist plausible, $P K^{\prime}$ s critique operates by causing religion to expose itself in the course of an innocently ignorant but logical 'bare humanist' sincerely attempting to practice it.

Both films ultimately discount the option of radical irreligion in favour of a form of humanist spirituality or religious reform that juxtaposes the social and institutional aspects of religion with more direct and pure connections of love, not only between individuals and God but also among humans. While $O M G$ contrasts love with fear, $P K$ articulates and engages more directly with the failures of love, both of God and between Jaggu and Sarfaraz or Jaggu and PK, who 'goes native' when he eventually falls in love with Jaggu and lies about it. The failure of love is linked to the breakdown of immediacy and communication across human-made and therefore ultimately spurious differences and distances, be they between religious communities, nations, or even between humans and God. This is again symbolized by PK's bare humanism as the ground 'beneath' the surface of acquired differences: PK's original nudity is the foil against which gender and especially religious difference register merely as a surface of sartorial practices: men wear shirts, women wear skirts, Hindus wear saffron, Sikh men have turbans, Muslim men grow beards, Muslim women are covered in black, Hindu women wear white if they are widowed, but Christian women wear white if they are about to get married and so forth. PK's initial inability to use language functions in a similar way: he must physically touch humans in order to communicate with them, but he finds himself incapable of doing so without violating norms of heterosocial and homophobic behaviour instituted on the basis of gender difference. He only finds direct human contact 'below' conventional standards of moral propriety, namely in the arms of a sex worker, whose (chaste) touch channels into him a 'sub-standard' dialect of Hindi. This conjures up the notion of a presumably authentic realm of popular and/ or rural culture supposedly less estranged from the bare humanity underneath the artifices of human 'civilization'. ${ }^{3}$ 
Whether sophisticated or popular, verbal language is necessary for PK's survival and his quest among humans, yet it also opens the gate to both insincerity and misunderstanding. It thus serves as the primary model for the film's concept of human culture as a system of communication that, like any medium, both connects and separates. As PK is told that only God can help him, the film's critique of religion unfolds through his gradual insight into the cultural function-or rather malfunction-of religions as social institutions mediating between humans and God. The decisive turn of the story occurs when PK grasps the use of non-literal speech. He suddenly understands the concepts of prank, joke and lie and finally realizes the role of intentional duplicity in the malfunctioning of religious communication: God is unresponsive not because he went 'missing', as he assumed initially, but because people have misdialled and called the wrong number of godmen and what he calls 'duplicate gods'. His frustration turns into anger, as he gains awareness of the common atheist critique of religious institutions as fraudulent manipulators, rather than mediators, which do not connect but separate people from both God and one another.

$P K$ rehearses a common repertoire of critique shared by atheists and religious reformers alike in a way that invites viewers to perceive them as utterly self-evident from an unbiased and neutral point of view, rather than from a position already marked as atheist, as is the case in $O M G$. Kanji needed the secular state's religious neutrality as an external counterbalance, whereas the alien PK himself embodies a form of ideal (Indian) secularity, which combines an equidistant neutrality with a positive, transcendent identification of spirituality as the principle of unity in diversity. In $P K$, the role of private media is not to connect state and society but to provide the public forum for the alien PK to perform an exemplary secularity as a model for both state and citizens. However, the final, televised showdown between PK and Tapasvi Maharaj secures this secularity by establishing the impossibility of atheism and banishing the horror vacui of irreligion. Tapasvi Maharaj asks PK if he desires a world without God and how he proposes to fill the void he creates by snatching away the hope that God represents for people. Remembering his own experience of material destitution, social isolation and despair, PK agrees to the 
necessity of God but juxtaposes a false god that humans create to the god that created humans, about whom they know nothing.

The default atheism of bare humanism emerges here as a merely rhetorical and narrative device that constructs an impossible scenario in order to enable $P K^{\prime}$ s religious critique. This critique is based on an abstract idea of a human being outside society and culture that can only be inhabited by an actual alien — or be imagined as a state of inebriated lunacyas it inevitably leads to unviable social deviance and dysfunctionality. PK finds himself constantly attacked, beaten and chased by angry mobs for his transgressive behaviour that violates socially instituted differences. His nudity is both utterly vulnerable and offensive (it also sparked a major controversy around the film; see Qadri and Mufti 2016). The extraterrestrial otherness of bare humanism also returns at a different scale of foreignness in Jaggu's and Sarfaraz's subplot, whose story of interreligious and international love can only be imagined in the extra-national space of foreign Europe (cf. Dwyer 2017). Ultimately, PK has to leave earth, even though the movie ends with his return a year later with an extended team of alien researchers.

\section{Conclusion}

Even though both films are invested in a reform of religion and ultimately deny the viability of atheism, they do not shy away from trenchant criticism of existing religions, especially in their institutionalized forms, by portraying positions of explicit irreligion (Kanji) and total alienness to religion (PK). My reading of $O M G$ and $P K$ proposes, however, that it is neither a lack of belief nor, more precisely, an ontological question of the existence of god(s) that determine atheism's impossibility, but a pervasive discourse on the social nature of religion. Religion may be deemed benevolent, harmful or amenable to reform, but the idea that it is not only linked to but in some way constitutive of sociality —and thus constitutive of 'society' as the substrate of the imagined community of the nation (cf. Anderson 1983) —is shared by many atheists, religious reformers, apologists and, I might add, scholars of religion. The discourse on the social function of religion as both the basis of an innermost sense 
of self and communal and national belonging is pervasive, in so far as it is the framework within which the positions of critic, reformer and apologist are enabled and differentiated in the first place.

In his discussion of anti-conversion legislation in India, Nathaniel Roberts describes this understanding of religion as a 'sedimented modernist common sense' (2016: 116) that is shared across the political spectrum of national elites in India, from secular liberals to Hindu nationalists, because it has been constitutive of both anticolonial and postcolonial nationalisms. While Roberts analyses this 'national frame' (ibid.: 111) in order to explain why conversion from one religion to another is considered deeply problematic, even by those who oppose legal bans on conversion, I argue that it also frames the impossibility of not belonging to any religion. Robert's ethnographic study of conversion among Dalits in a Chennai slum is particularly interesting for my argument because he shows that his interlocutors operate not only with a different understanding of religion but also with reference to a discourse of a basic humanity devoid of human-made and exploitative differences of nation, religion and, above all, caste.

My point is not that this is necessarily the 'same' humanism as that endorsed by my atheist interlocutors in Andhra Pradesh and Telangananor the 'alien humanism' depicted in $P K$-because, to start with, one is 'illegal' and the other 'impossible'. The comparison of atheism with conversion is instructive precisely because it shows how they are both entwined with complex, historically constituted grids of social, political and economic difference and marginalization, in so far as the problem of conversion is habitually displaced on to Dalits, Adivasis or women, who are considered particularly vulnerable to the lures of conversion (ibid.: 7), whereas the impossibility of atheism tends to be associated with 'Westernized', cerebral and culturally deracinated elites.

However, just as Dalits have their own ideas about religion and conversion, atheists do not simply resign themselves to the impossibility of atheism. To be suspended in the national frame of religious nationalism and state secularism does not entail consent or ideological alignment, which is borne out by the popularity and largely positive assessment of $O M G$ and $P K$ among my atheist interlocutors, despite the films' ambivalent messages about atheism. As scholarship on the production of 
imagined national communities has amply demonstrated, mass-mediated projects of national pedagogy do not require their addressees to believe in or be persuaded by specific media messages, especially since those media messages are not pre-existing, seamless, coherent wholes (Mankekar 1999; Rajagopal 2001; Abu-Lughod 2005; Meyer 2015); rather, the efficacy of state- and/or media-led projects of nation-building operates on principles like 'familiarity', 'pervasiveness', 'iteration' or 'ubiquity' (Roy 2007: 18-19), thus ensuring that certain national frames become sedimented as common sense and thus provide the very terms in which dissent can possibly be voiced.

In this chapter, I have approached $O M G$ and $P K$ as instances of nationalist iterations of atheism's impossibility, while the conditions for atheists' dissent seem comparable to what Susan Harding calls 'narrative encapsulation' (2000: 65). With this concept, she describes a condition of cultural hegemony in which a subordinate group has no choice but to use the terms and premises of a dominant discourse in order to frame and articulate not only its own story but also its very opposition to that discourse. In Harding's case, this meant that at a certain point in time, namely after the so-called Scopes trials, Christian fundamentalists in the USA had to conceptualize their opposition to a specific form of secular (not non-religious!) modernity as defeat. In a similar way, the currently hegemonic discursive framework of Indian religious nationalism and state secularism compels atheists to conceptualize their opposition to that framework as impossibility.

By no means does this imply that they simply agree with the depictions of impossible atheism in $O M G$ or $P K$. Since both films rehearse all major tropes of atheist critique from an unmistakably affirmative perspective, the stories' eventual turn against atheism is criticized as a half-hearted and cowardly move on the part of producers, directors and scriptwriters, who simply do not have the guts to go all the way. After all, the condition of narrative encapsulation does not refer to a situation in which an opponent's image is simply internalized, but one in which one's self-image is constituted in and on the opponent's terms. If atheists appreciate $O M G$ s and $P K$ 's depictions of atheist impossibility, they do not appreciate them as a correct representation of the reality of atheism but as a correct representation of the problems in realizing it. More concretely, my atheist 
interlocutors were aware of but rejected the films' attempts to transform an atheist critique of religion into an instance of religious critique or reform. They maintained a discursive slippage between the two that allowed them to construe the films as simply unequally sincere, consistent or gutsy versions of the same phenomenon: an atheism whose practical realization as irreligion is made impossible by its social framing at both the intradiegetic level of the films' narratives and the extradiegetic level of their production.

My aim in analysing the cinematic renderings of atheism in $O M G$ and $P K$ was to demonstrate that it is possible to study the historical production, social contextualization and diversity of atheism's impossibility. The two films represent two very different forms or characters of atheism, which are configured differently with regard to the secular state, the public sphere, the media and religious pluralism. While both films speak to themes and issues that may be specific or even unique to India or Indian religious nationalism, the direct adaptation of an Australian film in the case of $O M G$ and a more subtle, maybe unintentional, similarity to George Gurdjieff's (1950) novel Beelzebub's Tales to His Grandson in the case of $P K^{4}$ indicate that they are also part of a larger 'international frame'. Again, I do not mean to imply that impossibility articulates an essential, universal or transhistorical truth about atheism. Instead, the task of an anthropology of atheism is to analyse how the transactional global history of discourses like religious nationalism or state secularism continues to shape and transform the conditions in which atheism becomes impossible, possible or something else entirely.

\section{Notes}

1. In the context of the problematic political and moral claims of narratives of secular and/or liberal modernity as a legacy of the European Enlightenment and its particular forms of 'rational' critique, it is important to distinguish between religious critique, which may include projects of religious reform but also go beyond it, and the critique or criticism of religion, which may but need not necessarily entail a principled rejection of one or all religions or of religion as such (for a more detailed discussion, 
see Asad et al. 2009; Ahmad 2017). In the case at hand, however, I argue that the impossibility of atheism, in the sense of a basic discursive assumption rather than an explicit critique of atheism, is premised precisely on the ability to gloss over the distinction between critique and criticism and to let one slide into the other.

2. As a striking example for this process, my atheist interlocutors frequently mentioned their interpretation of the historical development of Buddhism as a process of 'Hinduization' (haindavikarana), whereby the Buddha's originally atheist and rationalist critique of Brahmanism was gradually transformed into a new religion that eventually transformed the Buddha himself into a new deity.

3. In $O M G$, the realm of the 'common people' was depicted as the locus of an ineradicable and self-propelling tendency towards religion, which is entirely immune to forms of rational critique and therefore requires a secular state to regulate religions in a neutral and unsentimental way. The realm of the popular in $P K$, by contrast, evokes a different discourse. As mentioned in the introduction, it construes the common people as the locus of cultural syncretism and forms of social solidarity beyond the divisive logic of communalism or secularism instituted by the modern nation state. Both discourses associate the popular with a state of 'uncultured' authenticity but assign very different valuations to it by conceptualizing it either as the breeding ground for obstinately superstitious religiosity or as the repository of a wholesome way of life that will cure the ailments of modern fragmentation (cf. Binder 2018).

4. I thank Vivek Kumar for bringing Gurdjieff's novel to my attention.

\section{References}

Abu-Lughod, L. 2005. Dramas of Nationhood: The Politics of Television in Egypt. Chicago: The University of Chicago Press.

Ahmad, I. 2009. Islamism and Democracy in India the Transformation of Jamaate-Islami. Princeton: Princeton University Press.

. 2017. Religion as Critique: Islamic Critical Thinking from Mecca to the Marketplace, Islamic Civilization and Muslim Networks. Chapel Hill: University of North Carolina Press.

. 2019. Democracy as Rumor: Media, Religion, and the 2014 Indian

Elections. In The Algebra of Warfare-Welfare: A Long View of India's 2014 
Election, ed. I. Ahmad and P. Kanungo, 55-90. New Delhi: Oxford University Press.

Anderson, B.R. 1983. Imagined Communities: Reflections on the Origin and Spread of Nationalism. London: Verso.

Appadurai, A. 1981. The Past as a Scarce Resource. Man 16 (2): 201-19.

Asad, T., et al. 2009. Is Critique Secular? Blasphemy, Injury, and Free Speech.

Berkeley: Doreen B. Townsend Center for the Humanities.

Bajpai, A. 2018. Speaking the Nation: The Oratorical Making of Secular, Neoliberal India. New Delhi: Oxford University Press.

Bhargava, R., ed. 1998. Secularism and its Critics. Delhi: Oxford University Press. Bhrugubanda, U.M. 2018. Deities and Devotees: Cinema, Religion, and Politics in South India. Delhi: Oxford University Press.

Binder, S. 2018. From Secularism to Popular Progressiveness: Popular Religion and the Creation of Telangana Regionalism. In The Secular in South, East and Southeast Asia, ed. K. Dean and P.T. van der Veer, 239-260. New York: Palgrave Macmillan.

. 2019. Aesthetics of the Secular. In Bloomsbury Handbook of the Cultural and Cognitive Aesthetics of Religion, ed. A. Koch and K. Wilkens, 263-272. London: Bloomsbury Academic.

- 2020. Total Atheism: Secular Activism and the Politics of Difference in South India. New York: Berghahn.

Blackburn, S. 2003. Print, Folklore, and Nationalism in Colonial South India. Delhi: Permanent Black.

Blanes, R.L., and G. Oustinova-Stjepanovic, eds. 2015. Being Godless: Ethnographies of Atheism and Non-Religion (Special Issue). Social Analysis 59 (2): $1-145$.

Chatterjee, M. 1983. Gandhis Religious Thought. London: Macmillan.

Chidester, D. 2014. Empire of Religion: Imperialism and Comparative Religion. Chicago: The University of Chicago Press.

Couldry, N. 2004. Theorising Media as Practice. Social Semiotics 14 (2): 115-132. Dalmia, V. 1997. The Nationalization of Hindu Traditions: Bhäratendu Hariśchandra and Nineteenth-Century Banaras. Delhi: Oxford University Press. Datla, K.S. 2013. The Language of Secular Islam. New Delhi: Orient BlackSwan. Dwyer, R. 2017. Calling God on the Wrong Number: Hindu-Muslim Relations in PK (2014) and Bajrangi Bhaijaan (2015). The Muslim World 107 (2): 256-270.

Gora. 1972. Positive Atheism. Vijayawada: Atheist Centre. 
Gurdjieff, G. 1950. Beelzebub's Tales to His Grandson: Or an Objectively Impartial Criticism of the Life of Man. New York: Harcourt.

Harding, S.F. 2000. The Book of Jerry Falwell: Fundamentalist Language and Politics. Princeton: Princeton University Press.

Jones, K.W. 1989. Socio-Religious Reform Movements in British India. Cambridge: Cambridge University Press.

Keane, W. 2013. Secularism as a Moral Narrative of Modernity. Transit: Europäische Revue 43: 159-170.

Kelly, J.D. 2001. Represented Communities Fiji and World Decolonization. Chicago: The University of Chicago Press.

Khilnani, S. 2007. Nehru's Faith. In The Crisis of Secularism in India, ed. A.D. Needham and R. Sunder Rajan, 89-106. Durham, NC: Duke University Press.

Kippenberg, H.G. 2001. Discovering Religious History in the Modern Age. Translated by B. Harshaw. Princeton: Princeton University Press.

Laidlaw, J. 2014. The Subject of Virtue: An Anthropology of Ethics and Freedom. Cambridge: Cambridge University Press.

Lee, L. 2015. Recognizing the Non-Religious: Reimagining the Secular. Oxford: Oxford University Press.

Lutgendorf, P. 1990. Ramayan: The Video. The Drama Review 34 (2): 127-176. Mahmood, S. 2016. Religious Difference in a Secular Age: A Minority Report. Princeton: Princeton University Press.

Mankekar, P. 1999. Screening Culture, Viewing Politics: An Ethnography of Television, Womanhood, and Nation. Durham, NC: Duke University Press.

Masuzawa, T. 2005. The Invention of World Religions: Or, How European Universalism Was Preserved in the Language of Pluralism. Chicago: The University of Chicago Press.

Meyer, B. 2009. Introduction: From Imagined Communities to Aesthetic Formations: Religious Mediations, Sensational Forms, and Styles of Binding. In Aesthetic Formations: Media, Religion, and the Senses, ed. B. Meyer, 1-28. New York: Palgrave Macmillan.

- 2015. Sensational Movies: Video, Vision, and Christianity in Ghana. Oakland: University of California Press.

Needham, A.D., and R. Sunder Rajan, eds. 2007. The Crisis of Secularism in India. Durham, NC: Duke University Press.

Qadri, M., and S. Mufti. 2016. Films and Religion: An Analysis of Aamir Khan's PK. Journal of Religion \& Film 20 (1): 31. 
Quack, J. 2012. Organised Atheism in India: An Overview. Journal of Contemporary Religion 27 (1): 67-85.

Radice, W., ed. 1999. Swami Vivekananda and the Modernisation of Hinduism. Delhi: Oxford University Press.

Rajagopal, A. 2001. Politics After Television: Religious Nationalism and the Reshaping of the Indian Public. Cambridge: Cambridge University Press.

Roberts, N. 2016. To Be Cared For: The Power of Conversion and Foreignness of Belonging in an Indian Slum. Berkeley: University of California Press.

Roy, S. 2007. Beyond Belief: India and the Politics of Postcolonial Nationalism. Durham, NC: Duke University Press.

Scheer, M., et al., eds. 2019. Secular Bodies, Affects, and Emotions: European Configurations. London: Bloomsbury Academic.

Sethi, M. 2012. Escaping the World: Women Renouncers among Jains. London: Routledge.

Tejani, S. 2008. Indian Secularism: A Social and Intellectual History 1890-1950. Bloomington: Indiana University Press.

Thomas, R. 2017. Atheism and Unbelief Among Indian Scientists: Towards an Anthropology of Atheism(s). Society and Culture in South Asia 3 (1): 45-67. van der Veer, P.T. 1994. Religious Nationalism: Hindus and Muslims in India. Berkeley: University of California Press.

- 2001. Imperial Encounters: Religion and Modernity in India and Britain. Princeton: Princeton University Press.

- 2014. The Modern Spirit of Asia: The Spiritual and the Secular in China and India. Princeton: Princeton University Press.

Venkatadri, R. 2007. Nēnū Nāstikuṇnēe. In Nāstikatvaṃ, 179-195. Chirala: Hema Publications. 
Open Access This chapter is licensed under the terms of the Creative Commons Attribution 4.0 International License (http://creativecommons.org/ licenses/by/4.0/), which permits use, sharing, adaptation, distribution and reproduction in any medium or format, as long as you give appropriate credit to the original author(s) and the source, provide a link to the Creative Commons licence and indicate if changes were made.

The images or other third party material in this chapter are included in the chapter's Creative Commons licence, unless indicated otherwise in a credit line to the material. If material is not included in the chapter's Creative Commons licence and your intended use is not permitted by statutory regulation or exceeds the permitted use, you will need to obtain permission directly from the copyright holder.

(c) (i) 